\title{
PENINGKATAN KEMAMPUAN BERHITUNG 1-20 MELALUI PERMAINAN PUZZLE DI TK TUNAS MUDA KOTA BANGUN
}

\author{
INCREASING CALCULATION ABILITY 1-20 THROUGH PUZZLE GAMES CHILDREN \\ Sunarno, Gina Indah Pitriani, Farny Sutriany Jafar \\ Universitas Mulawarman \\ farny.sutriany@yahoo.com
}

\begin{abstract}
ABSTRAK
Untuk mengetahui peningkatkan kemampuan berhitung 1-20 melalui permainan puzzle di TK Tunas Muda Kota Bangun. Penelitian ini dilaksanakan di TK Tunas Muda Kota Banguan semester 2 tahun 2016/2017. Subjek dalam penelitian adalah anak di TK Tunas Muda Kota Bangun. Pelaksanaan pembelajaran adalah penelitian, Teknik pengumpulan data di lakukan melaui dokumentasi dan lembar observasi. Observasi di lakukan padasaat proses pembelajaran, penelitian ini dilaksanakan dalam 3 siklus, yaitu siklus I, siklus II, dan siklus III, setiap siklusnya sebanyak 2 kali pertemuan. Hasil penelitian menunjukan pada siklus I diperoleh nilai rata-rata yaitu 49,65\% (Kurang), pada siklus II nilai rata-rata $61,45 \%$ (Cukup), pada siklus III niali rata-rata 77,08\% (Baik). karean kriteria sudah baik dan nilai yang diperoleh adalah \&gt; $70 \%$ sesuai target sehingga pada siklus III dikatakan berhasil. Dengan demikian dapat disimpulkan bahwa peningkatan kemampuan berhitung melalui permainan puzzle di TK Tunas Muda mengalami peningkatan.
\end{abstract}

\section{Kata Kunci : Kemampuan Berhitung, Media, Puzzle}

\section{ABSTRACT}

To find out how to improve 1-20 math skills through puzzle games at Tunas Muda Kindergarten, Kota Bangun. This research was conducted at Tunas Muda Kindergarten Banguan City in semester 2 of 2016/2017. Subjects in the study were children in TK Tunas Muda Kota Bangun. The implementation of learning is research, data collection techniques are done through documentation and observation sheets. Observations were made at the time of the learning process, this research was carried out in 3 cycles, namely cycle I, cycle II, and cycle III, each cycle consisting of 2 meetings. The results showed in the first cycle obtained an average value of $49.65 \%$ (Less), in the second cycle an average value of $61.45 \%$ (Enough), in the third cycle the average value was $77.08 \%$ (Good). because the criteria are good and the value obtained is \& gt; 70\% according to the target so that in cycle III it is said to be successful. Thus it can be concluded that the increase in numeracy skills through puzzle games in TK Tunas Muda has increased

Keywords: Ability to Calculate, Media, Puzzle

\section{PENDAHULUAN}

Anak usia dini merupakan pendidikan yang sangat mendasar dan sangat menentukan bagi perkembangan anak dikemudian hari. Menurut UU No. 20 Tahun 2003 pasal 1 ayat 14 menyatakan bahwa, Pendidikan Anak Usia Dini adalah suatu upaya pembinaan yang ditujukan sejak lahir sampai usia enam tahun, yang dilakukan dengan pemberian rangsangan pendidikan 
untuk pertumbuhan dan perkembangan jasmani dan rohani agar siap memasuki pendidikan yang lebih lanjut. Pada rentang usia ini anak mengalami masa usia keemasan (golden age), yang merupakan masa dimana anak mulai peka atau sensitif untuk menerima berbagai rangsangan Didalam persiapan menyusun model pembelajaran berhitung ini disesuaikan dengan karakteristik anak, perkembangan fisik dan psikologis, keadaan lingkungan sekitar dan ketersediaan saran dan prasarana pendidikan sangat mendukung keberhasilan pembelajaran anak. Kegiatan berhitung ini untuk meningkatkan kreatifitas anak sesuai dengan tahap perkembangannya. Dengan menggunakan jari tangan atau menyebutkan bilangan tanpa media, atau menggunakan tulisan yang terjadi di TK Tunas Muda, hal tersebut tidak membuat anak termotivasi dalam mengikuti proses pembelajaran, karena anak merasa kurang tertarik dan membosankan. Dengan demikian, maka diperlukan media yang membuat anak tertantang untuk mempelajarinya.

Berdasarkan data disekolah TK Tunas Muda Kota Bangun, dalam mengenalkan berhitung masih menggunakan jari atau pun tulisan angka, sehingga anak kurang tertarik dalam proses pembelajaran, akibatnya dalam mengembangkan logika matematika khususnya dalam mengenalkan berhitung jadi terhambat, dan berdasarkan fakta tersebut dari jumlah 12 anak hanya $1(8,33 \%)$ orang anak yang dapat berhitung atau menyebutkan angka 1-20 secara urut, dan jika guru menyebutkan angka 3 ataupun 6 anak mampu menunjuknya dengan benar, sedangkan 11 $(91,66 \%)$ anak lainnya belum mampu berhitung atau menyebutkan urutan bilangan dengan tepat,

\section{METODE PENELITIAN}

\section{Jenis Penelitian}

Penelitian ini dilakukan untuk memecahkan masalah dalam proses pembelajaran. Penelitian ini tergolong dalam penelitian tindakan kelas.Menurut Suharsimi Arikunto (2011:3) mengatakan bahwa "Penelitian Tindakan Kelas merupakan satu pencermatan terhadap kegiatan belajar berupa sebuah tindakan yang sengaja dimunculkan dan terjadi dalam sebuah kelas secara bersama".Suharsimi Arikunto( 2011:2-3 ), menjelaskan pengertian PTK secara lebih sistematis yaitu :

1. Penelitian adalah menunjuk pada suatu kegiatan mencermati suatu obyek dengan menggunakan cara dan aturan metodelogi untuk memperoleh data atau informasi yang 
bermanfaat dalam meningkatkan mutu suatu hal yang menarik minat dan penting bagi peneliti.

2. Tindakan adalah menunjuk pada suatu gerak yang sengaja dilakukan dengan tujuan tertentu. Penelitian berbentuk rangkaian siklus kegiatan untuk siswa.

3. Kelas adalah sekelompok siswa yang dalam waktu yang sama, menerima pelajaran yang sama dari guru yang sama pula.

\section{Waktu dan Tempat Penelitian}

1. Tempat Penelitian

Penelitian dilaksanakan di TK Tunas Muda Kota Bangun

2. Waktu

Waktu penelitian ini dimuali di semester genap tahun pembelajaran 2016/2017.

\section{Subjek dan Objek Penelitian}

1. Subjek Penelitian

Subjek Penelitian ini dilakukan pada anak di TK Tunas Muda kecamatan Kota Bangun pada tahun ajaran 2016/2017.

2. Objek Penelitian

Obyek penelitian ini adalah kemampuan berhitung 1-20 melalui permainan puzzle di TK Tunas Muda Kota Bangun.

\section{Prosedur Penelitian}

Rencana PTK ini dilaksanakan dengan tiga siklus setiap siklus dilaksanakan berdasarkan perencanaan yang sudah dirancang sebelumnya. Menurut Arikunto (2011) ada beberapa hal yang dilaksanakan dari tiap tahap yaitu perencanaan, pelaksana tindakan, observasi dan refleksi, yaitu

a. Perencanaan

1) Membuat instrument penelitian untuk anak dan proses pembelajaran 
2) Membuat Rencana Pelaksanaan Pembelajaran Mingguan (RPPM) dan Rencana Pelaksanaan Pembelajaran Harian(RPPH) dan Mempersiapkan media pembelajaran puzzle.

3) Mempersiapkan materi pembelajaran yang akan disampaikan.

4) Membuat evaluasi setiap tahap hasil penelitian, agar dapat mengetahui hasil dari Penelitian Tindakan Kelas

b. Pelaksanaan Tindakan

Pelaksanaan Tindakan Kelas, dilakukan pada saat kegiatan pembelajaran di TK Tunas Muda Kecamatan Kota Bangun untuk membahas pembelajaran yang sesuai dengan tema melalui permainan puzzle.

c. Observasi

Dalam tahap ini dilakukan $\mathrm{n}$ pengamatan terhadap pelaksanaan tindakan kelas dengan menggunakan lembar pengamatan yang telah disiapkan peneliti.

d. Refleksi

Kegiatan refleksi untuk mengungkapkan perubahan yang terjadi dalam proses pembelajaran dengan permainan puzzle, berupa :kemajuan yang dicapai anak dan guru, kekurangan dan kendala yang dihadapi dalam setiap tindakan, sehingga dapat melihat perubahan yang muncul.

\section{Teknik Pengumpulan Data}

1. Observasi, menururArikunto (2011:229) adalah pengamatan sebagai pertimbangan kemudian format yang disusun berisi item-item tentang kejadian atau tingkah laku yang digambarkan.

2. Dokumentasi, menurut Arikunto (2011:158) adalah mencari dan mengumpulkan data mengenai hal-hal yang berupa catatan, agenda, masalah dan sebagainya.

\section{Teknik Analisis Data}

Teknik analisis yang digunakan dalam penelitian ini dengan uraian Observasi dan Dokumentasi karena analisis ini berkaitan tentang peningkatan kemampuan berhitung 1-20 melalui permainan puzzle, teknik tersebut mengungkap kelemahan dan kelebihan anak dalam proses belajar mengajar. Hasil analisis ini nantinya akan sebagai dasar untuk menyusun 
perencanaan tindakan kelas. Zainal Aqib (2011:40) memaparkan bahwaanalisis data penelitian tindakan kelas dapat dihitung menggunakan rumussebagai berikut :

1. Mencari nilai rat-rata

$$
\mathrm{X}=\frac{\sum X}{\sum N}
$$

Keterangan :

$$
\begin{aligned}
& X=\text { nilai rata }- \text { rata } \\
& \sum=\text { jumlah semua nilai siswa }
\end{aligned}
$$

$$
N=\text { jumlah siswa }
$$

2. Mencari nilai ketuntasan belajar

$$
\boldsymbol{P}=\frac{\sum \text { Siswa yang tuntas belajar }}{\sum \text { siswa }} \times 100 \%
$$

\section{HASIL PENELITIAN DATA DAN PEMBAHASAN}

Pada siklus I dinyatakan masih belum berhasil karena pada siklus I ini kegiatan belajar berhitung 1-20 dilakukan tanpa menggunakan media, anak berhitung 1-20 masih menggunakan jari tangan, oleh sebab itu anak kurang tertarik untuk mengikuti kegiatan belajar mengajar.

PadaSiklus II masih dinyatakan belum berhasil, walaupun belum berhasil sudah ada 2 orang anak yang sudah bisa berhitung secara urut dan mencocokkan kepingan gambar puzzle dengan angka.

Pada Siklus III ini, penelitian dinyatakan berhasil, karena anak sudah bisa menyebutkan angka bila dilihatkan lambing bilangannya, berhitung secara urut, dan mencocokkan kepingan gambar puzzle dengan angka.Nilai rata-rata anak terus meningkat darisiklus I ke Siklus II dan Siklus III. 


\section{SIMPULAN DAN SARAN}

\section{Simpulan}

Berdasrkan seluruh hasil penelitian tindakan kelas yang telah dilakukan pada anak didik di kelompok B TK Tunas Muda Kota Bangun dapat disimpulkan bahwa melalui kegiatan bermain puzzle, kemampuan kognitif anak dapat ditingkatkan. Perbaikan dan dan penyempurnaan kegiatan permainan puzzle akan bermanfaat dalam usaha meningkatkan kemampuan kognitif anak usia prasekolah. Hal ini diperlukan sebagai landasan bagi tahap berkembangan selanjutnya dalam upaya meningkatkan sumber daya manusia dimasa yang akan datang, karean salah satu aspek yang menjadi tujuan pendidikan anak usia dini adalah berkembangnya kemampuan gerak dasar yang akhirnya akan berpengaruh terhadap kognitif anak.

Kamampuan berhitung 1-20 anak setelah melalui tindakan kegiatan bermain puzzle yang telah dirancang peneliti bersama guru, pada umumnya mengalami peningkatan yang bertahap pada tiap siklusnya. Pada tahap awal pra siklus sebesar 8,33\%, pada siklus I pertemuan I dan II diperoleh rata-rata 49,65\%, dan anak yang memperoleh kategori baik dan baik sekali 8,33\%, pada siklus II pertemuan I dan II meningkat menjadi 61,45\%, dan anak yang memperoleh kategori baik dan baik sekali 16,66\%,pada siklus III pertemuan I dan II sebesar 77,08\%, dan anak yang memperoleh kategori baik dan baik sekali $100 \%$.

\section{Saran}

Dunia anak adalah dunia bermain, dengan bermain anak-anak sebenarnya belajar dan bermain. Salh satu cara bagi orang tua untuk melatih kemampuan anak sejak dini adalah melali permainan puzzle, banyakamanfaat yang bisa diperoleh dari permainan puzzle, seperti mengasah kemampuan berfikir anak dalam menyimpulkan letak gambar sesuai logika, melatih koordinasi tangan dan mata, serta melatih daya konsentrasi dan kesabaran anakdalam menyesuaikan sebuah permaian puzzle.

Dalam hal perkembangan kemampuan kognitif anak melaui berbagai kegiatan salah satunya dengan permainan puzzle ternyata memberi manfaaat dan dampak positif terhadap perkembangan kognitif anak. 


\section{DAFTAR PUSTAKA}

AranithaEriene. 2014. Peningkatan Kemampuan Kognitif Anak dengan Permainan Puzzle Kelompok B di TK Kartika V-12 Samarinda Tahun Ajaran 2013/2014.Skripsi. FKIP Universitas Mulawarman Samarinda

Arikunto, Suharsimi, Suharjono, dkk, 2011. Penelitian Tindakan Kelas. Jakarta :Bumi Aksara

Depdiknas. 2007. Pedoman Pembelajaran Permainan Berhitung Permulaan diTaman Kanakkanak.Dirjen Pembinaan Taman Kanak-kanak dan Sekolah Dasar, Jakarta

Mujito. 2007. Permainan Berhitung Permulaan. DepPenNas. Jakarta

Peraturan Menteri Pendidikan dan Kebudayaan Republik Indonesia no. 146 th 2014

Sujiono, NurainiYuliani. 2008. MetodePengembanganKognitif.Jakarta: Universitas Terbuka 